\title{
OXIDIZED DIPHENYLAMINE AS A SPECTROPHOTOMETRIC REAGENT FOR THE DETERMINATION OF SOME PHARMACEUTICAL THIOLS AND THIOAMIDES
}

\author{
K. M. Emara ${ }^{1}$, I. H. Refaat ${ }^{*}$, H. M. Abdel-Wadood ${ }^{1}$ and M. G. Hassan ${ }^{2}$ \\ ${ }^{1}$ Department of Pharmaceutical Analytical Chemistry, Faculty of Pharmacy, Assiut University, \\ Assiut, Egypt \\ ${ }^{2}$ Department of Pharmaceutical Analytical Chemistry, Faculty of Pharmacy, Al-Azhar \\ University, Assiut, Egypt
}

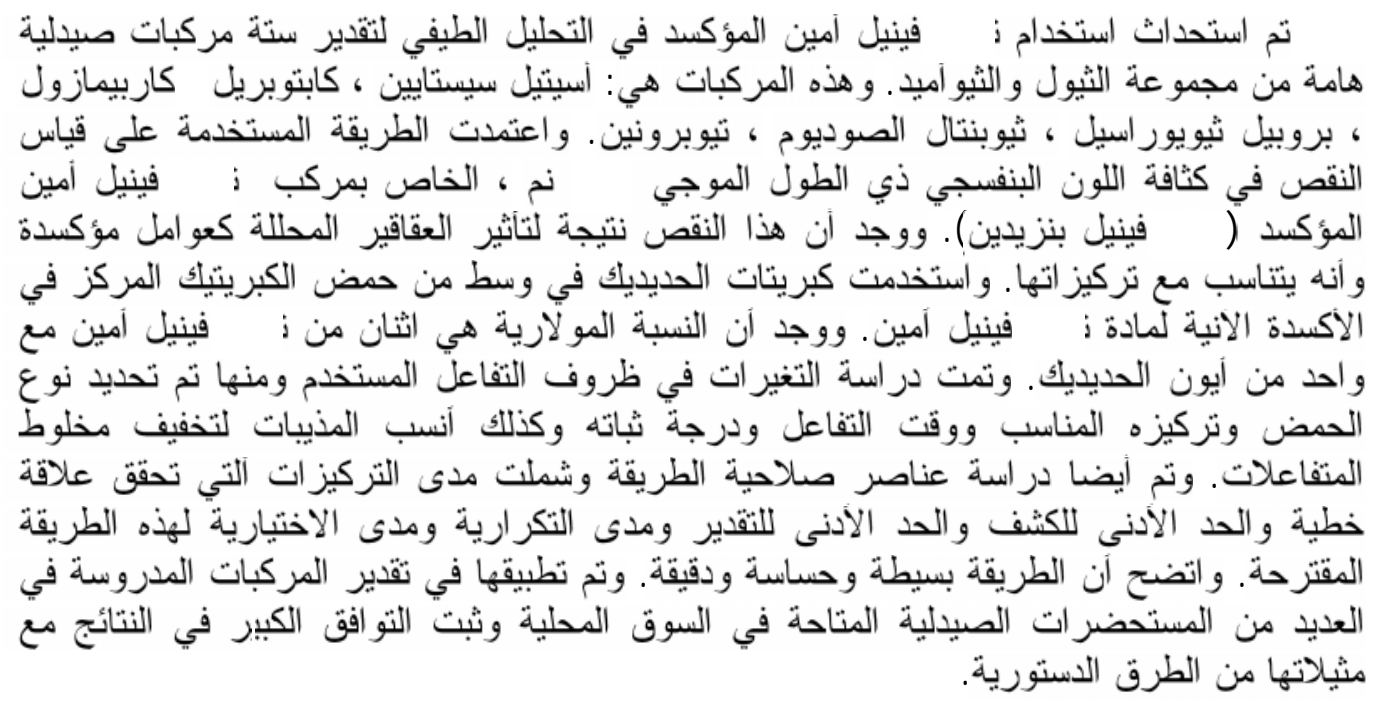

Oxidized diphenylamine is newly utilized as a redox spectrophotometric reagent for the determination of six pharmaceutically important thiol and thioamide drugs named: acetylcystiene, captopril, carbimazole, propylthiouracil, thiopental sodium, and tiopronin. The method is based on measurement of the decrease in absorption intensity of the oxidized diphenylamine (diphenylbenzidine violet, $\lambda \max =580 \mathrm{~nm}$ ) reagent as a result of the reduction effect of the analysed drugs. This reagent was instantaneously prepared by the oxidation of diphenylamine using ferric sulphate in sulphuric acid medium. The molar ratio of the chromogen reagent was determined to be $2: 1$; diphenylamine : iron (III). The decrease in colour intensity was found to be quantitatively dependant on drug concentration. Experimental variables including reagent concentration, acid type and concentration, dilution solvent, reaction time, temperature and stability were studied and optimized. Validation parameters including linearity range, detection and quantitation limits, precision, selectivity and robustness were evaluated. The proposed method was found to be simple, sensitive and accurate one indicated by the studied validation parameters. Good recoveries $(98.0 \pm 0.14-100 \%, \pm 0.98)$ were obtained by the suggested method and it was applied for the determination of the studied drugs in many pharmaceutical dosage forms available in the local market. Good agreement, indicated by acceptable $t$ - \& F-tests, was found between results obtained by the suggested method and those obtained by the reported or pharmacopoeial methods. 


\section{INTRODUCTION}

Thiols and thioamides represent an important class of compounds with an intensive and interesting chemistry and pharmacology. $\mathrm{N}$ - Acetylcysteine is a mucolytic drug. Also it has a key role in the management of paracetamol overdosage. Captopril is a thiol drug that has been used in management of hypertention, in heart failure, following myocardial infarction and in diabetic nephropathy. Carbimazole is used in the management of hyperthyrodism, the treatment of Grave's disease, the preparation of hyperthyroid patients for thyroidectomy, as an adjunct to radio-iodine therapy and treatment of thyroid storm. Propylthiouracil is used in the management of hyperthyrodism. Thiopental is an intravenous anesthetic drug. Tiopronin is used for management of cysteinuria, rheumatoid arthritis, hepatic disorders, heavy metals poisoning and as mucolytic in respiratory disorders. ${ }^{1,2}$ The chemical structures $^{3}$ of the studied drugs are shown in Table 1.

Diphenylamine and its family are redox titrimetric indictors. In the presence of oxidants e.g. potassium dichromate, it undergoes an irreversible oxidative coupling reaction to yield diphenylbenzidine which is also colourless. However, upon further oxidation, it is converted into a bright purple compound knawn as diphenylbenzidine violet. ${ }^{4}$ On the other hand, diphenylamine has been previously utilized to produce a chromogen which is structurally methylene blue like dye as a condensation product with oxidized phenothiazine compounds. N-bromosuccinimide was used phenothiazine oxidation and this method was applied for the colourimetric determination of many drugs in their pharmaceutical dosage forms. ${ }^{5}$ Oxidized diphenylamine derivatives have been previously utilized and reviewed for the spectrophotometric determination of $\mathrm{ClO}_{4}{ }^{-}$, $\mathrm{ReO}_{4}^{-}, \mathrm{Ir}(\mathrm{IV}), \mathrm{Ru}(\mathrm{IV})$, and $\mathrm{Au}(\mathrm{III}){ }^{6}$

In this work, oxidized diphenylamine is newly utilized as a chromogen for the spectrophotometric determination. It has been successfully applied on the determination of six thiol and thioamide drug compounds of medicinal value.
Many analytical methods have been published for the analysis of the studied thiols and thioamids. Concerning colorimetric methods reported for the determination of the studied drugs, some selected methods are shown in Table 2.

\section{EXPERIMENTAL}

\section{Apparatus}

1. UV-1601 PC, UV-Visible Spectrophotometer (Shimadzu, Japan).

2. Ultrasonic cleaner (Cole-Parmer, Chicago, USA).

3. A sensitive balance (Precisa, Presisa Instruments Ltd., Switzerland).

4. MLW type, thermostatically controlled water bath (Achtung, Germany).

\section{Materials}

Diphenylamine (Merck, Darmstadt, Germany), Iron (III) sulfate (Winlab Co., UK), carbimazole (Cid Co., Talbya, Giza, Egypt), captopril (Bristol, Meyers Squibb), Acetylcysteine (Sedico, $6^{\text {th }}$ of October, Cairo, Egypt), thiopental sodium (EIPICO, $10^{\text {th }}$ of Ramadan, Cairo, Egypt), propylthiouracil (Amoun Pharm. Co., El-obour city, Cairo, Egypt) and tiopronin (Aldrich Co., USA), ammonium vanadate (Winlab Co., UK), ceric ammonium sulfate (Sigma Co. St. Louis, USA) and p-dimethylaminobenzaldehyde (Winlab Co., UK). All drugs were used as working standards without further purification. They were analyzed according to official or reported methods to determine their purity and compliance with the pharmaceutical requirements.

Analytical grade sulfuric acid, perchloric acid, nitric acid, hydrochloric acid, acetic acid, acetonitrile, methanol, ethanol and acetone were used throughout this study. Double distilled water was used throughout the work.

\section{Formulations}

Pharmaceutical preparations listed in Table 3 were purchased from the local market and subjected to analysis by the proposed procedure. Tiopronin tablets were laboratory prepared as synthetic mixture according to reported requirements. ${ }^{37,41}$ 
Table 1: Chemical structures ${ }^{3}$ of the studied thiol and thioamide drugs.

\begin{tabular}{||l|l|l||}
\hline Drug & \multicolumn{2}{|c|}{ Molecular } \\
Weight
\end{tabular}


Table 2: Some selected colorimetric methods used for the determination of the studied thiol and thioamide drugs.

\begin{tabular}{|c|c|c|c|}
\hline Drug & \multicolumn{2}{|r|}{ Colorimetric reagent } & Ref. \\
\hline N-Acetylcysteine & \multicolumn{2}{|c|}{$\begin{array}{l}\text { Palladium (II), and cobalt-ethylenediamine tetraacetate (EDTA). } \\
\text { Fe (III) -ferrozine and sodium perchlorate. }\end{array}$} & $\begin{array}{l}7 \\
8\end{array}$ \\
\hline Captopril & \multicolumn{2}{|c|}{$\begin{array}{l}\text { Citric acid, acetic anhydride } \\
\text { Potassium bromate and celestine blue. } \\
\text { Fe (III) and 1, 10- phenanthroline. } \\
\text { Sodium nitrite. } \\
\text { Folin- Ciocalteu. } \\
\text { Ammonium molybdate and phosphoric acid in presence of } \mathrm{Cu} \text { (II). } \\
\text { Fe (III) and Potassium ferricyanide in sulfuric acid medium. } \\
\text { Ellman's and N-ethylmaleimide reagents. } \\
\text { Azure A and B. } \\
\text { Metol and dichromate in phthalate buffer. } \\
\text { Cu (II) and neocuproine. } \\
\text { Tetrazolium blue. } \\
\text { Methylbenzothiazolinone hydrazone (MBH) and diamine-2 } \mathrm{HCl} \text {. } \\
\text { Phosophotungestic acid. } \\
\text { N-bromophthalimide and molybdophosphoric acid. } \\
\text { Iodine-starch complex. } \\
\text { Fe (III) and 2,2 '-bipyridyl. } \\
\text { Sodium nitrite and cresyl fast blue. } \\
\text { 7, 7, 8, 8-Tetracyanoquinodimethane (TCNQ). }\end{array}$} & $\begin{array}{l}9 \\
10 \\
11 \\
12 \\
13 \\
14 \\
15 \\
16 \\
17 \\
18 \\
19 \\
20 \\
21 \\
22 \\
23 \\
23 \\
24 \\
25 \\
26\end{array}$ \\
\hline Carbimazole & \multicolumn{2}{|c|}{$\begin{array}{l}\text { Potassium dichromate and molybdate. } \\
\text { Potassium bromate, bromide and flourescien. } \\
\text { Mercurochrome. }\end{array}$} & $\begin{array}{l}27 \\
28 \\
29\end{array}$ \\
\hline Propylthiouracil & \multicolumn{2}{|c|}{ Neutral red and hypophosphite. } & 30 \\
\hline Thiopental sodium & \multicolumn{2}{|c|}{$\begin{array}{l}\text { Chloranil, Chloranilic acid and dichlone. } \\
\text { Dinitrobindone. } \\
\text { Sodium nitroprusside in basic medium. } \\
\text { Flouranil, 2, 4, 7-trinitro-9-fluorenone, 7, 7, 8, 8-tetracyanoquino- } \\
\text { dimethane, chloranil, chloranilic acid and tetracyanoethylene. } \\
\text { Sodium metaperiodate and brucine. }\end{array}$} & $\begin{array}{l}31 \\
32 \\
33\end{array}$ \\
\hline Tiopronin & \multicolumn{2}{|c|}{$\begin{array}{l}5,5^{\text {' }} \text {-dithiobis- (2-nitrobenzoic acid). } \\
\text { Tetrachloropalladate. }\end{array}$} & $\begin{array}{l}36 \\
37\end{array}$ \\
\hline \multicolumn{2}{|c|}{ N- Acetylcysteine \& tiopronin } & Fe (III) and 1,10-phenanthroline. & 38 \\
\hline \multicolumn{2}{|l|}{ Captopril \& tiopronin } & $\begin{array}{l}\text { 4-Chloro-7-nitro-benzofurazan. } \\
\text { 2, 6-Dichloroquinone-4-chlorimide (DQC). } \\
\mathrm{KMnO}_{4} \text {-hematoxylin. }\end{array}$ & $\begin{array}{l}39 \\
40 \\
41\end{array}$ \\
\hline \multicolumn{2}{|c|}{ Captopril \& thiopental sodium } & 2, 3-Dichloro-1,4-naphthoquinone (Dichlone). & 42 \\
\hline \multirow{2}{*}{\multicolumn{2}{|c|}{$\begin{array}{l}\text { Carbimazole \& thiopental sodium } \\
\text { Carbimazole \& propylthiouracil }\end{array}$}} & Hematoxylin-chloramine $\mathrm{T}$. & 43 \\
\hline & & Palladium (II) and pyronine G. & 44 \\
\hline
\end{tabular}


Table 3: The studied commercial and laboratory prepared pharmaceutical preparations.

\begin{tabular}{||l|l|l|l||}
\hline $\begin{array}{c}\text { Pharmaceutical } \\
\text { Preparation }\end{array}$ & \multicolumn{1}{|c|}{ Ingredients } & $\begin{array}{c}\text { Nominal } \\
\text { Content } \\
(\mathrm{mg})\end{array}$ & \multicolumn{1}{|c||}{ Manufacturer } \\
\hline Acetylcysteine & Acetylcysteine & $200 /$ backet & Sedico, $6^{\text {th }}$ of October, Cairo, Egypt \\
\hline Mucomyst & Acetylcysteine & $200 /$ backet & Bristol Meyers, Squibb \\
\hline Capoten & Captopril & $25 /$ tablet & Bristol Meyers, Squibb \\
\hline Capotril & Captopril & $50 /$ tablet & EPICO, 10 ${ }^{\text {th }}$ of Ramadan, Cairo, Egypt \\
\hline Capozide & $\begin{array}{l}\text { Captopril }+ \\
\text { Hydrochlorothiazide }\end{array}$ & $\begin{array}{l}50 / \text { tablet } \\
25 / \text { tablet }\end{array}$ & Bristol Meyers, Squibb \\
\hline Carbimazole & Carbimazole & $5 /$ tablet & CID, Giza, Egypt \\
\hline Thyrocil & Propylthiouracil & $50 /$ tablet & $\begin{array}{l}\text { Amoun Pharm. Co., El-obour city, } \\
\text { Cairo Egypt. }\end{array}$ \\
\hline $\begin{array}{l}\text { Thiopental } \\
\text { sodium }\end{array}$ & Thiopental sodium & $1000 /$ vial & EPICO,10 $0^{\text {th } \text { of Ramadan, Egypt. }}$ \\
\hline Tiopronin & Tiopronin & $\begin{array}{l}0.3 / 50 \mathrm{~g} \\
\text { mix. }\end{array}$ & Lab. prepared mixture. \\
\hline
\end{tabular}

\section{Reagents and solutions}

Iron (III) sulfate solution

Aqueous solution of iron (III) sulfate $\left(2 \times 10^{-3} \mathrm{M}\right)$ was prepared by dissolving $80 \mathrm{mg}$ in $100 \mathrm{ml}$ distilled water.

\section{Diphenylamine solution}

A solution of $\left(4 \times 10^{-3} \mathrm{M}\right)$ was prepared daily by dissolving $70 \mathrm{mg}$ of diphenylamine in $100 \mathrm{ml}$ concentrated sulfuric acid.

\section{Preparation of standard solutions}

An accurately weighed amount of each of the studied drugs was transferred into a 100-ml volumetric flask, dissolved in about $50 \mathrm{ml}$ of acetonitrile then completed to the mark with the same solvent to provide a stock standard solution containing about $0.70 \mathrm{mg} / \mathrm{ml}$. The working standard solutions were prepared by further dilution with the same solvent to obtain concentrations covering the range of 4-700 $\mu \mathrm{g} / \mathrm{ml}$. The stock and working standard solutions were kept refrigerated in light protected flasks.

\section{Preparation of sample solutions Tablets and laboratory prepared mixture}

Twenty tablets were weighed, finely powdered and mixed thoroughly. An accurately weighed amount of the powdered tablets equivalent to about $20 \mathrm{mg}$ of the drug was transferred into 100-ml volumetric flask containing about $50 \mathrm{ml}$ of acetonitrile. The contents were shaken well for 15 minutes then completed to $100 \mathrm{ml}$ with the same solvent. The resulting solution was filtered off rejecting the first portion of the filtrate. The prepared solution was then diluted quantitatively with the same solvent to obtain about $300 \mu \mathrm{g} / \mathrm{ml}$ captopril, $50 \mu \mathrm{g} / \mathrm{ml}$ carbimazole, $200 \mu \mathrm{g} / \mathrm{ml}$ propylthiouracil and $200 \mu \mathrm{g} / \mathrm{ml}$ tiopronin.

\section{Backets}

Content of twenty backets were accurately weighed and a quantity equivalent to $25 \mathrm{mg}$ of the drug was transferred into $100 \mathrm{ml}$ volumetric flask and the procedures were completed as under tablets to obtain about $250 \mu \mathrm{g} / \mathrm{ml}$ acetylcysteine.

\section{Vials}

The content of 10 vials were mixed thoroughly and an accurately measured amount equivalent to about $40 \mathrm{mg}$ of the drug was transferred into $100-\mathrm{ml}$ volumetric flask and the procedures were completed as under tablets to obtain about $40 \mu \mathrm{g} / \mathrm{ml}$ thiopental sodium.

\section{Molar ratio of diphenylamine-iron (III) sulfate combination}

Job's method ${ }^{45}$ of continuous variation was employed. Equimolar $\left(2 \times 10^{-3}\right)$ solutions of each of iron (III) sulfate and diphenylamine were prepared. A series of $10 \mathrm{ml}$ portions of mixtures of $1: 9,2: 8,3: 7,4: 6,5: 5,6: 4,7: 3,8: 2$, 9:1 (Iron(III) sulfate $\left(2 \times 10^{-3} \mathrm{M}\right):$ diphenylamine 
$\left(2 \times 10^{-3} \mathrm{M}\right)$ were made up in different complementary proportions in $10-\mathrm{ml}$ calibrated flasks. The flasks were heated in a thermostatically controlled water bath for 2-3 minutes at $60^{\circ}$ and the absorbances of the solutions were measured at $580 \mathrm{~nm}$.

\section{General assay procedure}

Into a 10-ml calibrated flask, one $\mathrm{ml}$ of iron (III) sulfate $\left(2 \times 10^{-3} \mathrm{M}\right)$ and one $\mathrm{ml}$ of diphenylamine $\left(4 \times 10^{-3} \mathrm{M}\right)$ were mixed. The contents of the flask were heated in a thermostatically controlled water bath for 2-3 minutes at $60^{\circ}$. One $\mathrm{ml}$ of the standard or the sample preparation in the range of 4.0-700.0 $\mu \mathrm{g} / \mathrm{ml}$ was added and the solutions were heated again at $60^{\circ}$ for $5 \mathrm{~min}$. The reaction mixture was then cooled and diluted to the mark with acetonitrile. The decrease in absorbance was measured at $580 \mathrm{~nm}$. against blank which was prepared similarly omitting the addition of drug sample.

\section{RESULTS AND DISCUSSION}

\section{Spectral characteristics}

Diphenylamine in the presence of iron(III) sulfate is oxidized into colorless diphenylbenzidine, which is reversibly further oxidized to diphenylbenzidine violet. ${ }^{46}$ The studied drugs namely, acetylcysteine, captopril, carbimazole, propylthiouracil, thiopental sodium and tiopronin have reducing properties, so they will decrease the intensity of the violet colour of diphenylbenzidine (Scheme 1). The amount of this decrease measured at $580 \mathrm{~nm}$ was found to be dependant on the drug concentration and could be used for their determinations (Fig. 1).

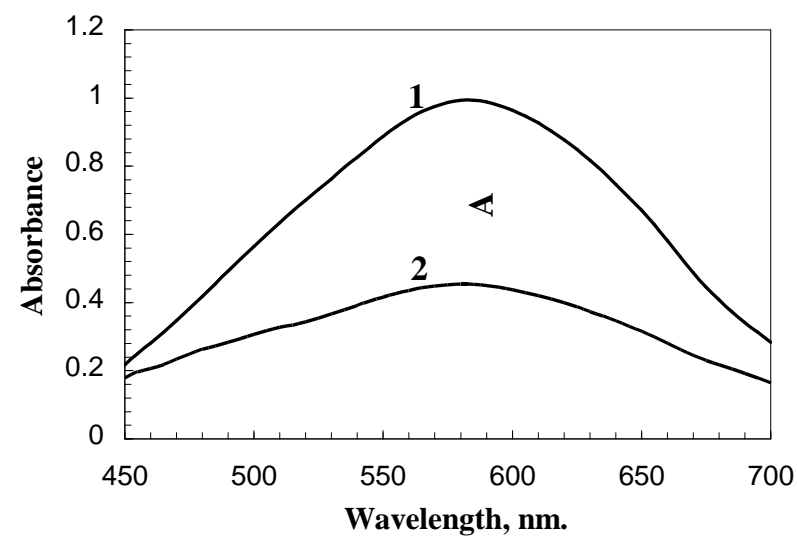

Fig. 1: Absorption spectrum of Fe (III) $\left(2 \times 10^{-3} \mathrm{M}\right)$ diphenylamine $\left(4 \times 10^{-3} \mathrm{M}\right)$ reagent $(\mathbf{1})$ and carbimazole (5 $\mathrm{g} / \mathrm{ml})$-reagent (2).

\section{Molar ratio of iron (III) sulfate-diphenyl- amine combination}

Using Job's method of continuous variation, ${ }^{45}$ the molar ratio of iron (III) sulfate : diphenylamine was found to be 1:2 (Fig. 2). Therefore, this reagent was prepared in that ratio for subsequent work.
2<smiles>c1ccc(Nc2ccccc2)cc1</smiles>

Diphenylamine
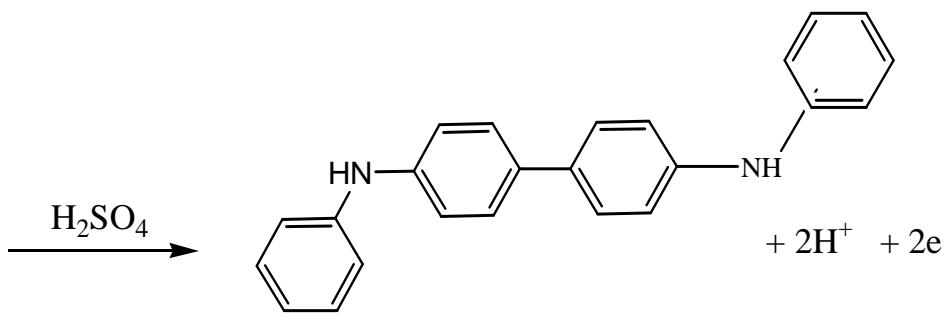

Diphenylbenzidine (colourless)

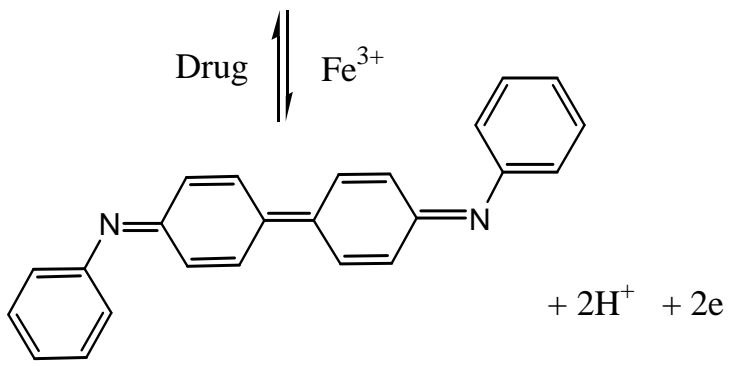

Diphenylbenzidine (violet)

Scheme 1, Suggested reaction mechanism 


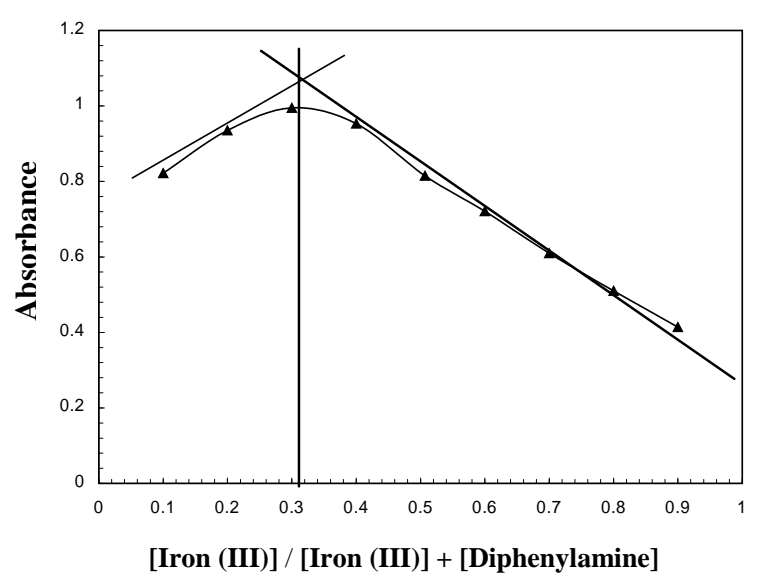

Fig. 2: Continuous variation plot obtained from solutions of iron (III) and diphenylamine $\left(2 \times 10^{-3} \mathrm{M}\right)$.

\section{Optimization of variables}

Various parameters affecting the reaction conditions including, reagent concentration, acid type and concentration, dilution solvents, reaction time and stability were investigated and optimized for all the studied drugs.

\section{1- Concentration of the reagent}

According to the above mentioned reaction involved, iron (III) sulfate and diphenylamine were prepared by mixing them in the ratio of 1:2. The selected concentration of this reagent which gave the highest absorption value within the practical sensitivity range of absorbance $(0.9 \sim 1.0)$ was found to be $\left(2 \times 10^{-3} \mathrm{M}\right)$ iron (III) sulfate and $\left(4 \times 10^{-3} \mathrm{M}\right)$ diphenylamine.

\section{2- Acid type and concentration}

As represented in scheme 1, it is clear that the oxidation reaction of diphenylamine requires an acid medium. Therefore, different acids such as sulfuric, perchloric, nitric, hydrochloric and acetic were tested to determine the most suitable acid for the reaction. It was noticed that, perchloric acid and nitric acid, in absence of iron(III) sulfate, cause oxidation of diphenylamine indicated by the formation of the violet color of diphenylbenzidine violet. Hydrochloric acid and acetic acid did not form the violet color upon addition of iron (III) sulfate solution; may be due to the reducing properties of hydrochloric acid and the lower acidity strength of acetic acid. So, sulfuric was selected as a suitable acid for the preparation of the reagent. It was preferably added as a dissolution solvent for diphenylamine.

The effect of the concentration of sulfuric acid used for this dissolution was studied using different concentrations ranged from 4-18 $\mathrm{M}$. Concentrated sulfuric acid (i.e. $18 \quad \mathrm{M}$ ) developed the maximum color intensity upon addition of ferric sulfate solution. So, it was selected for this purpose.

\section{3- Dilution solvents}

Water, methanol, ethanol, acetonitril and acetone were tried for dilution of the reaction mixture. Captopril $(30 \mu \mathrm{g} / \mathrm{ml})$ and carbimazole (5 $\mu \mathrm{g} / \mathrm{ml}$ ) were used as a representative examples for this experiment. It was noticed that water causes fading of the produced color while, acetonitrile gave maximum absorption difference ( A) (Table 4). So, acetonitrile was selected as dilution solvent for subsequent work.

Table 4: Effect of different dilution solvents on absorption intensity.

\begin{tabular}{|c|c|c|}
\hline \multirow{2}{*}{ Solvent } & \multicolumn{2}{|c|}{ Absorption difference $(\Delta \mathrm{A})^{*}$} \\
\cline { 2 - 3 } & Carbimazole** & Captopril** \\
\hline Acetonitrile & 0.538 & 0.525 \\
\hline Methanol & 0.384 & 0.421 \\
\hline Ethanol & 0.345 & 0.389 \\
\hline Acetone & 0.254 & 0.287 \\
\hline
\end{tabular}

* Average of three determinations.

** Concentration used; $5 \mu \mathrm{g} / \mathrm{ml}$ carbimazole and $30 \mu \mathrm{g} / \mathrm{ml}$ captopril.

The effect of water used for the preparation of iron (III) sulphate reagent is compensated by the high acidity of sulphuric acid used and the presence of acetonitrile as an organic solvent present in the reaction mixture.

\section{4- Reaction time and temperature of iron(III) sulfate-diphenylamine combination}

The reaction time between iron (III) sulfate $\left(2 \times 10^{-2} \mathrm{M}\right)$ and diphenylamine $\left(4 \times 10^{-3}\right.$ M) was studied at three different temperature levels; 25,60 and $100^{\circ}$ using a thermostatically controlled water bath. It was found that at room temperature $\left(25^{\circ}\right)$, absorption intensity increases by increasing time, attaining maximum after $15 \mathrm{~min}$. At $60^{\circ}$, the maximum intensity was attained after $2-3 \mathrm{~min}$. At $100^{\circ}$, fading of the produced chromogen was found 
to increase with heating time (Fig. 3). Therefore, the water bath was controlled at $60^{\circ}$ for this work.

As shown in Fig. 3, the produced chromogen at $60^{\circ}$ is almost stable for at least $30 \mathrm{~min}$. Therefore, this temperature level was applied for the general assay procedure.

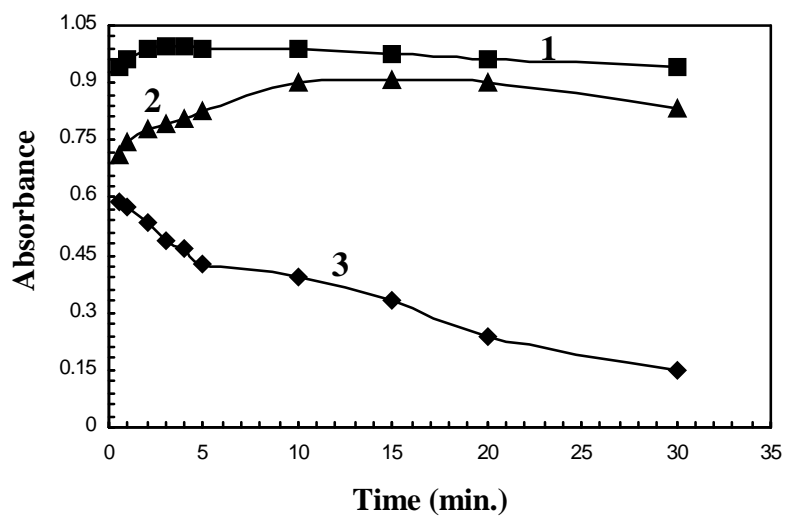

Fig. 3: developing time and stability of diphenylamine $\left(4 \times 10^{-3} \mathrm{M}\right)$ - Iron (III) $\left(2 \times 10^{-3} \mathrm{M}\right)$ at three temperature levels: (1) $60^{\circ}$, (2) $25^{\circ}$ and (3) $100^{\circ}$.

5- Reaction time and stability of drugoxidized diphenylamine combination

The reaction time between oxidized diphenylamine and studied drugs was studied at two temperature levels, 25 and $60^{\circ}$. It was found that at $25^{\circ}$, the absorbance difference attains its maximum after relatively longer time than that at $60^{\circ}$. In addition, this difference is usually higher at $60^{\circ}$ than it is at $25^{\circ}$ (Fig. 4; af). Therefore, $60^{\circ}$ temperature level was selected and optimal reaction time of $5 \mathrm{~min}$ was determined for the general assay procedure. The produced chromogen intensity was found to be almost stable for at least 15 min (Fig. 4; a-f).

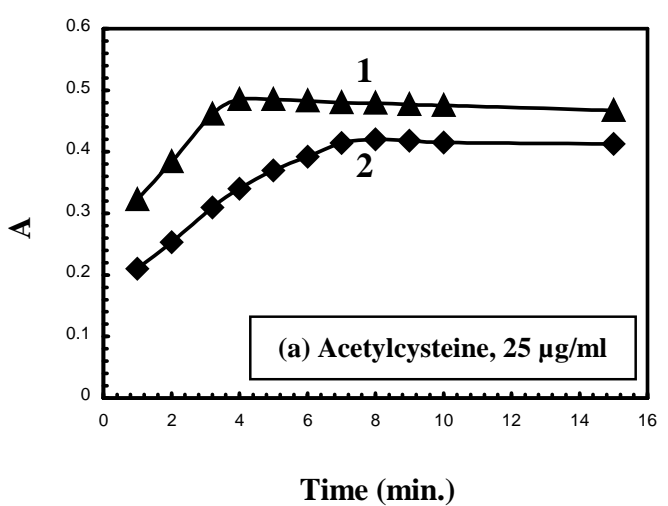

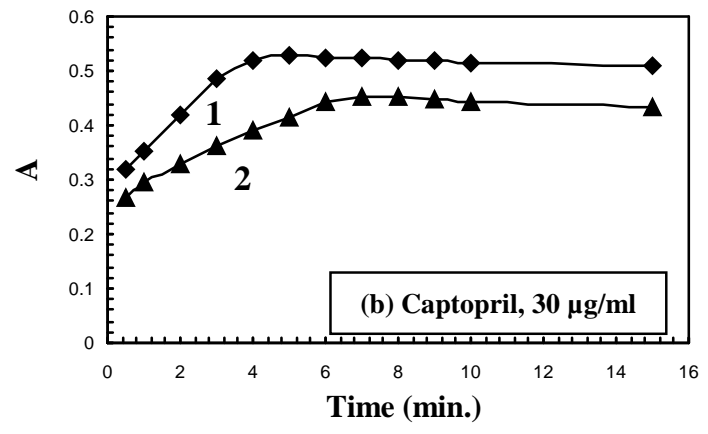
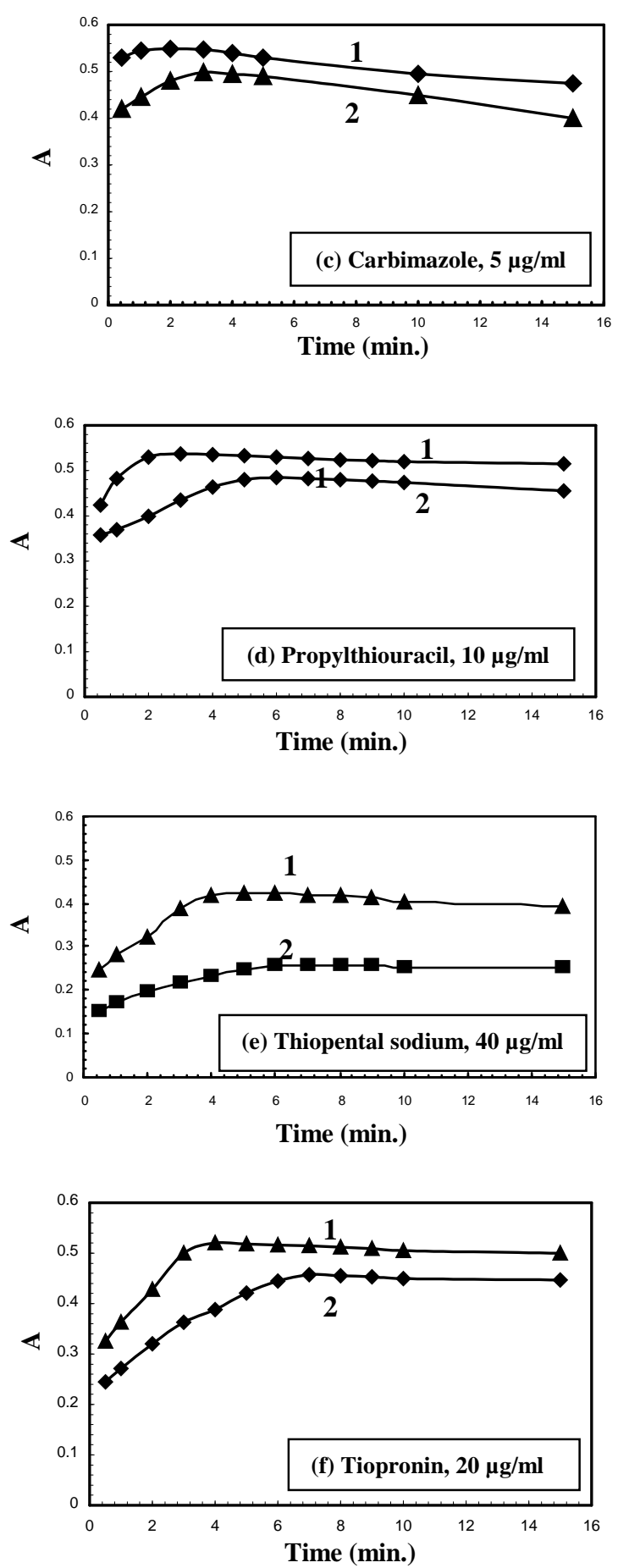

Fig. 4(a-f): Reaction time of drug-oxidized diphenylamine at two temperature levels; (1) $60^{\circ}$ and (2) $25^{\circ}$. 
Validation of the proposed method

1- Linearity, detection and quantitation limits

The calibration curves of the studied drugs were constructed by plotting absorbance difference versus drug concentration. Linear calibration graphs were obtained in the concentration range of final dilution cited in (Table 5). The slope (b) was used as a measure of the sensitivity of the proposed method, while the intercept (a) was used as a measure of the interfering background. Results indicate high sensitivity and low background effect of the proposed method. The correlation coefficients ranged from 0.9990-0.9998 indicating good linearity. Limit of detection (LOD) and limit of quantitation (LOQ) for the analytes were calculated according to the USP $2002^{47}$ as follows;

$$
\mathrm{LOD} \text { or LOQ }=\mathrm{K} . \sigma \mathrm{a} / \mathrm{b}
$$

Where, $K=3$, for $L O D$ and $K=10$, for $L O Q ; ~ \sigma$ a: is the standard deviation of the intercept (a) and $b$ : is the slope.

\section{2- Precision}

The precision of the proposed method was checked by replicate analysis of ten separate solutions of working standards of captopril and carbimazole as representative examples for the investigated drugs. The analysis was carried out at three concentration levels; 15,30 and 45 $\mu \mathrm{g} / \mathrm{ml}$ for captopril and 3,5 and $9 \mu \mathrm{g} / \mathrm{ml}$ for carbimazole. The obtained relative standard deviations were $1.302,1.251$ and $1.141 \%$ in case of captopril and 1.157, 1.297 and $1.308 \%$ in case of carbimazole. These results, being less than $2.0 \%$ indicate good repeatability.

\section{3- Selectivity}

In this study, the method was carried out for the analysis of captopril $(30 \mu \mathrm{g} / \mathrm{ml})$, as a representative example, in the presence of some common excipients and additives such as; starch, glucose, sucrose, gum acacia, lactose, $\mathrm{Mg}$-stearate and in the presence of hydrochlorothiazide. Good recoveries were obtained. Results shown in Table 6 indicate that the proposed method is able to access the analyte in presence of common excipients, so the proposed method can be considered a selective one.

\section{4- Robustness}

The robustness of the proposed method was carried out to evaluate the influence of small variation in the reaction conditions on the method suitability and sensitivity. Using captopril $(30 \mu \mathrm{g} / \mathrm{ml})$ and carbimazole $(5 \mu \mathrm{g} / \mathrm{ml})$ as representative examples, it was found that neither small variation on diphenylamine regent concentration nor small variation on reaction time significantly affects percentage recovery of the drug (Table 7). This provides an indication of reliability the proposed method during normal use of the method in determination of the studied drugs. So, the method is considered to be robust.

Table 5: Quantitative parameters and statistical data for the analysed drugs.

\begin{tabular}{|l|c|c|c|c|c|c|c|c|}
\hline \multicolumn{1}{|c|}{ Drug } & $\begin{array}{c}\varepsilon, \text { L.mole }^{-1} \\
\mathrm{~cm}^{-1}\end{array}$ & $\begin{array}{c}\text { Linearity range } \\
\mu \mathrm{g} / \mathrm{ml}\end{array}$ & LOD & LOQ & $\begin{array}{c}\text { Slope } \\
\pm(\mathrm{SE})\end{array}$ & $\begin{array}{c}\text { Intercept } \\
\pm(\mathrm{SE})\end{array}$ & $\mathrm{r}$ & $\mathrm{r}^{2}$ \\
\hline Acetylcysteine & 3114 & $4-40$ & 1.19 & 3.95 & $\begin{array}{c}0.0192 \\
(0.0003)\end{array}$ & $\begin{array}{c}-0.0114 \\
(0.0076)\end{array}$ & 0.9994 & 0.9988 \\
\hline Captopril & 4007 & $5-45$ & 1.35 & 4.49 & $\begin{array}{c}0.0189 \\
(0.0002)\end{array}$ & $\begin{array}{c}-0.0116 \\
(0.0085)\end{array}$ & 0.9993 & 0.9986 \\
\hline Carbimazole & 20445 & $0.4-9$ & 0.10 & 0.34 & $\begin{array}{c}0.1115 \\
(0.0067)\end{array}$ & $\begin{array}{c}-0.0071 \\
(0.0038)\end{array}$ & 0.9998 & 0.9996 \\
\hline Propylthiouracil & 9397 & $2-16$ & 0.48 & 1.59 & $\begin{array}{c}0.0527 \\
(0.0008)\end{array}$ & $\begin{array}{c}0.0225 \\
(0.0084)\end{array}$ & 0.9992 & 0.9985 \\
\hline $\begin{array}{l}\text { Thiopental } \\
\text { sodium }\end{array}$ & 2901 & $8-70$ & 2.31 & 7.69 & $\begin{array}{c}0.0113 \\
(0.0002)\end{array}$ & $\begin{array}{c}-0.0105 \\
(0.0087)\end{array}$ & 0.9992 & 0.9984 \\
\hline Tiopronin & 4352 & $4-35$ & 1.10 & 3.67 & $\begin{array}{c}0.0234 \\
(0.0004)\end{array}$ & $\begin{array}{c}0.0593 \\
(0.0086)\end{array}$ & 0.9993 & 0.9986 \\
\hline
\end{tabular}

LOD: Limit of detection; $\mu \mathrm{g} / \mathrm{ml}$, LOQ: Limit of quantitation; $\mu \mathrm{g} / \mathrm{ml}$, r: Correlation coefficient.

Table 6: Analysis of captopril in the presence of some common excipients and hydrochlorothiazide. 


\begin{tabular}{||l|c|c||}
\hline \multicolumn{1}{|c|}{ Ingredient } & Amount added (mg) & \% Recovery* \pm SD \\
\hline 1- Starch & 50 & $98.83 \pm 0.60$ \\
\hline 2- Glucose & 10 & $100.09 \pm 0.87$ \\
\hline 3- Sucrose & 50 & $99.65 \pm 0.91$ \\
\hline 4- Gum acacia & 10 & $98.55 \pm 1.04$ \\
\hline 5- lactose & 10 & $100.06 \pm 0.95$ \\
\hline 6- Mg- stearate & 10 & $98.78 \pm 0.87$ \\
\hline 7- Hydrochlorothiazide & 25 & $98.91 \pm 0.97$ \\
\hline
\end{tabular}

* Average of five determinations.

Table 7: Robustness of the oxidized diphenylamine method.

\begin{tabular}{|c|c|c||}
\hline \multirow{2}{*}{ Variation } & \multicolumn{2}{|c|}{ \% Recovery \pm SD } \\
\cline { 2 - 3 } & Carbimazole* & Captopril* \\
\hline $\begin{array}{c}\text { Oxidized diphenylamine } \\
\text { concentration (M): }\end{array}$ & & \\
$4.2 \times 10^{-3} \mathrm{M}$ & $99.12 \pm 0.91$ & $98.88 \pm 0.79$ \\
$3.8 \times 10^{-3} \mathrm{M}$ & $99.58 \pm 0.74$ & $98.97 \pm 0.87$ \\
\hline 5.5 & & \\
4.5 & $98.78 \pm 0.97$ & $99.14 \pm 0.98$ \\
\hline Reaction time (min): & $99.25 \pm 0.94$ & $99.54 \pm 0.74$ \\
\hline
\end{tabular}

* Drug concentration used; $30 \mathrm{~g} / \mathrm{ml}$ captopril and $5 \mathrm{~g} / \mathrm{ml}$ carbimazole.

Table 8: Analysis of studied drugs in their pharmaceutical preparation or laboratory prepared mixture.

\begin{tabular}{|c|c|c|c|c|c|}
\hline \multirow[b]{2}{*}{ Product } & \multirow{2}{*}{$\begin{array}{c}\text { Ingredient } \\
\text { (Content, mg) }\end{array}$} & \multicolumn{4}{|c|}{$\%$ Recovery* \pm SD } \\
\hline & & $\begin{array}{c}\text { Proposed } \\
\text { method }\end{array}$ & $\begin{array}{l}\text { Reference } \\
\text { method** }\end{array}$ & F-value & $\mathrm{t}$ - value \\
\hline $\begin{array}{l}\text { 1- Acetylcysteine } \\
\text { (backets) }\end{array}$ & $\begin{array}{l}\text { Acetylcysteine } \\
(200)\end{array}$ & $99.85 \pm 0.53$ & $99.5 \pm 0.94$ & 2.99 & 1.51 \\
\hline $\begin{array}{l}\text { 2-Mucomyst } \\
\text { (backets) }\end{array}$ & $\begin{array}{l}\text { Acetylcysteine } \\
(200)\end{array}$ & $99.13 \pm 0.42$ & $99.05 \pm 0.61$ & 2.13 & 1.27 \\
\hline $\begin{array}{l}\text { 3-Capoten } \\
\text { (tablets) }\end{array}$ & $\begin{array}{l}\text { Captopril } \\
(25)\end{array}$ & $99.71 \pm 0.83$ & $99.43 \pm 0.75$ & 1.22 & 1.17 \\
\hline $\begin{array}{l}\text { 4-Capotril } \\
\text { (tablets) }\end{array}$ & $\begin{array}{l}\text { Captopril } \\
(50)\end{array}$ & $99.82 \pm 0.67$ & $99.27 \pm 0.79$ & 1.39 & 1.41 \\
\hline $\begin{array}{l}\text { 5-Capozide } \\
\text { (tablets) }\end{array}$ & $\begin{array}{l}\text { Captopril } \\
(25)\end{array}$ & $99.55 \pm 0.72$ & $99.91 \pm 0.33$ & 4.63 & 1.07 \\
\hline $\begin{array}{l}\text { 6-Carbimazole } \\
\text { (tablets) }\end{array}$ & $\begin{array}{l}\text { Carbimazole } \\
(5)\end{array}$ & $97.98 \pm 0.98$ & $97.93 \pm 0.12$ & 1.52 & 0.78 \\
\hline $\begin{array}{l}\text { 7- Thyrocil } \\
\text { (tablets) }\end{array}$ & $\begin{array}{l}\text { Propylthiouracil } \\
(50)\end{array}$ & $99.18 \pm 0.43$ & $98.93 \pm 0.42$ & 1.09 & 1.05 \\
\hline $\begin{array}{l}\text { 8-Thiopental sodium } \\
\text { (vial) }\end{array}$ & $\begin{array}{l}\text { Thiopental sodium } \\
(1000)\end{array}$ & $99.72 \pm 0.14$ & $99.18 \pm 0.72$ & 3.65 & 1.61 \\
\hline $\begin{array}{l}\text { 9-Tiopronin } \\
\text { (mixture)*** }\end{array}$ & $\begin{array}{l}\text { Tiopronin } \\
(100)\end{array}$ & $99.18 \pm 0.43$ & $98.93 \pm 0.42$ & 1.09 & 1.05 \\
\hline
\end{tabular}

$*$ Average of six determinations \pm SD. $* * *$ Laboratory prepared mixture

**References No. $47 \& 48$.

Theoretical values at $95 \%$ confidence limit $\mathrm{t}=2.31$ and $\mathrm{F}=5.05$ 


\section{Application on pharmaceutical preparations}

Some commercial dosage forms of the studied drugs were successfully analyzed by the proposed and the official USP $2002^{47}$ and British Pharmacopoeia 1998. ${ }^{48}$ Recovery experiments were performed for each drug in its dosage forms. Results are shown in Table 8. Dosage forms of tiopronin are not available in local market, so its analysis was carried out using laboratory prepared mixture. There is no significant difference between results obtained by proposed, official or reported methods, as indicated by $\mathrm{t}$ - and $\mathrm{F}$ - tests (Table 8 ).

\section{REFERENCES}

1- S. C. Sweetman, "Martindale The Complete Drug Reference", $33^{\text {rd }}$ Ed., The Pharmaceutical Press, London, 2002, pp. $853,853,1025,1082,1083,1084,1521$ and 1522 .

2- H. P. Rang and M. M. Dale, "Pharmacology", $3^{\text {rd }}$ Ed., Churchill Livingstone, New York, 1987, pp. 270, 271, 431, 432 and 544.

3- A. C. Moffat, J. V. Jackson, M. S. Moss, B. Widdop and E. S. Greenfield, "Clarke's Isolation and Identification of Drugs", $2^{\text {ed }}$ Ed., The Pharmaceutical Press, London, 1986, pp. 318, 426, 427, 432, 433, 939, 1017 and 1018.

4- Robert B. Fischer and Dennis G. Peters, "Basic Theory and Practice of Quantitative Chemical Analysis", Third Ed., W.B. Saunders Company, London, 1968, p. 535.

5- Abdel-Maaboud I. Mohamed, Talanta, 44, 1173 (1997).

6- S. P. Musbrakova, N. N. Gusakova, N. N. Pankratov, E. E. Fedorov and L. A. Gribov, Zh. Anal. Khim., 39, 1010 (1984).

7- M. G. Soledad, C. Sanchez-Pedreno and M. I. Albero, Analyst, 115, 989 (1990).

8- M. A. Eid, Mikrochim. Acta., 129, 91 (1998).

9- J. Emmanuel and S. D. Halankar, Indian Drugs, 26, 319 (1989).

10- C. S. P. Sastry, S. G. Rao, P. Y. Naidu and K. R. Srinivas, Anal. Lett., 31, 263 (1998).

11- E. M. Mohamed, S. M. Tawakkol and Y. H. Aboul-Enein, Zentralbl. Pharm., Pharmakother. Laboratoriumsdiagn., 122,
1163 (1983), through Chem. Abstr., 100, 56941h (1984).

12- M. Y. Ebeid, B. A. Mousa, A. A. Abdel, Malek and F. M. Ashour, Bull. Fac. Pharm., Cairo Univ., 32, 349 (1994).

13- C. S. P. Sastry, T. R. Thirupathi, A. Sailaja and J. R. Venkatewsara, Indian Drugs, 28, 523 (1991).

14- M. S. Shingare and U. N. Kale, Indian Drugs, 37, 204 (2000).

15- F. M. Ashour, F.M. Salama and M. A. E. Aziza, J. Drug Res., 19, 323 (1990), through Chem. Abstr., 115, 263582s (1991).

16- M. A. Raggi, V. Cavrini, A. M. Di Petra and D. Lacche, Pharm. Acta Helv., 63, 19 (1988), through Chem. Abstr., 108, 173654t (1988).

17- S. A. Shama and A.S. Amin, Egypt. J. Chem., 43, 527 (2000).

18- C. S. P. Sastry, A. Sailaja and M. V. Suryanarayana, Indian Drugs, 28, 45 (1990).

19- W. X. Ma, Guangpuxue Yu Guangpu Fenxi., 19, 118 (1999), through Anal. Abstr., 61, 7G91 (1999).

20- A. Gumieniczek, D. Kowlczuk and L. Przyborowski, Acta Pol. Pharm., 55, 21 (1998), through Chem. Abstr., 129, 127287m (1998).

21- C. S. P. Sastry, A. Sailaja and T. Rao, Thirupathi, Pharmazie, 46, 465 (1991).

22- Z. Yi-Shu and W. Xiu-Li, Zhongguo Yiyao Gongye Zazhi, 25, 219 (1994), through Chem. Abstr., 121, 213168q (1994).

23- S. M. El- Ashry and F. A. Ibrahim, Anal. Lett., 25, 1657 (1992).

24- H. F. Askal, Talanta, 38, 1115 (1991).

25- C. S. P. Sastry, R. S. Kommula and M. M. K. P. Kommuri, Anal. Lett., 29, 1329 (1996).

26- A. M. El-Brashy, S. M. El-Ashry and M. B. El-Ashmawy, Alexandria J. Pharm. Sci., 5, 209 (1991).

27- S. M. Sultan, J. Pharm. Biomed. Anal., 10, 1059 (1992).

28- Y. S. El-Saharty, M. Abdel- Kawy and M. G. El-Bardicy, Spectrosc. Lett., 34, 325 (2001).

29- A. M. Korany, M. M. Bedair, M. A. Elsayed and O. T. Fahmy, Anal. Lett., 22, 1909 (1989). 
30- M. Barzegar, L. Rahmani, A. Jabbari and M. F. Mousavi, Pharmazie, 58, 114 (2003).

31- R. S. Bakry, O. A. Razak, A. F. A. ElWalily and S. F. Belal, S. T. P. Pharma Part., 5, 397 (1995), through Chem. Abstr., 124, 97876e (1996).

32- B. P. Zorya, V. V. Petrenko and V. V. Zaporozh, Farm. Zh., 4, 45 (1982), through Chem. Abstr., 97, 223060y (1982).

33- F. A. Ibrahim, Mansoura J. Pharm Sci., 10, 334 (1994).

34- G. A. Saleh, Talanta, 46, 111 (1998).

35- C. S. P. Sastry, P. Satyanrayana, N. R. P. Singh and R. A. R. Mohana, Acta Cienc. Indica, Chem., 14, 37 (1988), through Chem. Abstr., 111, 180870a (1989).

36- A. M. Raggi, M. R. Cesaroni and A. M. Di Pietra, Farmaco, Ed. Part., 38, 312 (1983), through Anal. Abstr., 46, 1E42 (1984).

37- A. M. Raggi, L. Nobile, V. Cavrini and A. M. Di Pietra, Boll. Chim. Farm., 125, 295 (1986), through Anal. Abstr., 49, 8E105 (1987).

38- M. A. Raggi, V. Cavrini and A. M. Di Pietra, J. Pharm. Sci., 71, 1384 (1982).

39- H. F. Askal, O. H. Abdelmaged and P. Y. Khashaba, Egypt. J. Anal. Chem., 4, 89 (1995).
40- M. E. El-Kommos, H. A. Mohamed, O. H. Abdelmageed and N. A. Mohamed, Bull. Pharm. Sci., Assiut Univ., 16, 131 (1993).

41- I. H. Refaat, Bull. Pharm. Sci., Assiut Univ., 18, 135 (1995).

42- M. M. Bedair, Alexandria J. Pharm. Sci., 5, 64 (1991).

43- C. S. P. Sastry, P. Satyanarayana, A. Rama, M. Rao and N. R. P. Singh, Indian Drugs, 26, 84 (1988).

44- M. S. Garcia, M. I. Albero and C. Sanchez Pedreno, Analyst, 120, 129 (1995).

45- T. Rose, "Advanced Physico-Chemical Experiments", Pitman, London, England, 1964, p. 54.

46- G. H. Jeffery, J. Bassett, J. Mendham and R. C. Denny, "Vogel's Textbook of Quantitative Chemical Analysis" $5^{\text {th }}$ Ed., Longmann Scientific \& Technique, UK, 1989, pp. 229, 366.

47- The United State Pharmacopoeia XXV and NF XX, US Pharmacopeial Convention INC., Twinbrook Parkawy, Rockville, MD, 2002, pp. 263, 264, 1482 and 1483.

48- British Pharmacopoeia, London, Her Majestry's Stationary Office London, Vol. 1, 1998, pp. 40,41, 244, 249, 1282 and 1283 . 